\title{
Latex sensitization in patients with myelomeningocele: contribution of microarray technique
}

Division of Allergy, Clinical Immunology and Rheumatology, Department of Pediatrics, Escola Paulista de Medicina-Federal University of São Paulo, São Paulo, Brazil

\section{KEY WORDS}

latex; myelomeningocele; recombinant allergens; latex-fruit syndrome; allergy

\section{Corresponding author}

Dirceu Solé

Rua dos Otonis 725

04025-002 Vila Mariana, SP, Brazil

Phone: + 551155791590

Fax: + 551155791590

E-mail: dirceu.sole@unifesp.br

Doi

10.23822/EurAnnACI.1764-1489.52

\begin{abstract}
Summary
Background. Microarray technique employing molecular allergens is pointed out as a new method to evaluate allergic patients. Objective. To evaluate if microarray technique (ImmunoCAP-ISAC ${ }^{\circledR}$; I-ISAC ${ }^{\circledR}$ ) is similar to fluorescence enzyme immunoassay (FEIA; ImmunoCAP ${ }^{\circledR}$ ) in the diagnosis of latex allergy (specific IgE to latex plus symptoms) and latex sensitization (only antibody) in pediatric (9-mo to 14-yrs) patients with myelomeningocele undergone to surgical repair. Methods. Patients underwent skin prick testing (SPT) to latex and food (prick to prick), and dosage of serum specific IgE to latex and recombinant latex allergens ( $r \mathrm{Hev} b 1, r \mathrm{Hev} b 3, r \mathrm{Hev} b 5, r \mathrm{Hev} b 6.01$, $r H e v ~ b 6.02, r H e v b 8, r H e v b$ 9, and rHev $b$ 11) by Immuno CAP ${ }^{\circledR}$ and I-ISAC ${ }^{\circledR}$. Results. The comparison between the two methods showed high level of concordance considering positive and negative results. A statistically significant correlation for $r \mathrm{Hev} b 3$ and $r \mathrm{Hev} b 6.01$ for the allergic patients, and for $r H e v 65$ and $r H e v$ b6.01 for those sensitized to latex, was observed. I-ISAC ${ }^{\circledR}$ is limited to 5 recombinant latex allergens ( $r H e v b$ 1, 3, 5, 6.01 and 8). Despite the presence of antibodies against pollens, LTP and profilins (I-ISAC $\left.{ }^{\circledR}\right)$ in some patients, none of them reported symptoms related with intake of fruits andlor vegetables. Conclusion. Both methods are effective in assisting the diagnosis of latex allergy, but differ in the assessment of sensitized pediatric patients with myelomeningocele. The assessment of latex sensitized patients is more complete using the 8 recombinant latex fractions available for ImmunoCAP ${ }^{\circledR}$, instead of I-ISAC ${ }^{\circledR}$.
\end{abstract}

\section{Introduction}

The recent advent of microarray technique employing molecular allergens represents a breakthrough for better evaluation of allergic patients, especially those with food allergy. This technique has allowed more extensive studies in allergic patients and provided a better understanding of cross-reactivity among different allergens, especially those derived from plants $(1,2)$. Patients allergic to latex may experience symptoms after eating certain foods, like fruits, vegetables and seeds. This characterizes the latex-pollen-fruit syndrome and is due to cross-reactivity of allergens from different sources called pan-allergens, such as lipid transfer proteins (LTP), storage proteins and profilins $(3,4)$. In a previous study, we evaluated the profile of latex sensitiza- tion/allergy in children and adolescents with myelomeningocele, followed up at a specialized center (5). We observed prevalence of sensitization and of allergy to latex among these children as $25 \%$ and $20 \%$, respectively (5). Specific IgE to $\mathrm{rHev}$ b $1, \mathrm{rHev}$ b 3, rHev b 5, rHev b 6.01, and $\mathrm{rHev}$ b 6.02 were detected in over $50 \%$ of children allergic to latex (presence of latex-specific $\mathrm{IgE}$ antibody plus clinical symptoms when exposed) (5). The higher frequency of specific $\mathrm{IgE}$ to $\mathrm{rHev}$ b 6.01, $\mathrm{rHev}$ b 6.02, and $\mathrm{rHev}$ b 5 than to $\mathrm{rHev} \mathrm{b} 3$ in our study was surprising, since the reports for this population indicate the opposite (5).

Determination of specific serum $\mathrm{IgE}$ against 8 recombinant Hevea brasiliensis allergen components was performed using a customized allergen microarray and a conventional fluorescence 
enzyme immunoassay (FEIA) in 52 adults with immediate-type natural rubber latex allergy (6). These authors concluded that natural rubber latex-specific $\mathrm{IgE}$ recognition patterns and sensitization rates determined by microarray analysis were similar to those obtained by FEIA (6).

Do the patients with myelomeningocele also have this concordance between these diagnostic methods? Furthermore, would the microarray be able to detect sensitization to other allergens related to latex? To clarify these questions, we studied whether the microarray technique was able to detect sensitization to latex in the same way as FEIA in pediatric patients with myelomeningocele. Additionally, we tried to find out whether there are advantages in performing the microarray technique instead of FEIA in these patients.

\section{Patients and methods}

Twenty-five children and adolescents (9 months to 14 years, mean $=7.3$ years) known to be sensitized to latex that had undergone surgical repair of myelomeningocele, followed at the Department of Neurosurgery of the Federal University of São Paulo, Brazil, were studied, as partially reported above (5).

Patients' parents or guardians were asked if their children had allergic diseases or symptoms, previous personal or family conditions related to corrective surgery of the myelomeningocele, or a current history of reaction to latex or foods. Patients underwent skin prick testing (SPT) to latex and food (prick to prick - avocado, apple, celery, chestnut, fig, jackfruit, kiwi, manioc, mango, melon, papaya, peach, pear, pineapple, potato and tomato) (7) and blood samples were obtained for quantification of specific IgE to latex and recombinant latex allergens ( $\mathrm{rHev} b \mathrm{~b}$, rHev b 3, rHev b 5, rHev b 6.01, rHev b 6.02, rHev b 8, rHev b 9 , and rHev b 11) by FEIA and microarray technique.
Specific IgE antibody levels in FEIA technique (ImmunoCAP ${ }^{\circledR}$, Thermo Scientific ${ }^{\circledR}$ ) were expressed in $\mathrm{kU} / \mathrm{L}$, and values equal to or greater than $0.35 \mathrm{kU} / \mathrm{L}$ were considered positive. Specific IgE antibody levels in microarray technique (I-ISAC ${ }^{\circledR}$; Thermo Scientific ${ }^{\circledR}$ ) were expressed in ISU (ISAC Standardized Units), and values equal to or greater than 0.3 were considered positive $(8,9)$. The study was approved by the Ethic Committee of Federal University of São Paulo, and all parents / guardians have signed an informed consent.

\section{Results}

Table 1 summarizes the concordance of results of specific IgE to recombinant latex allergens obtained by both methods and shows high concordance for both groups of patients (allergic and sensitized).

Table 2 presents the results of the SPT to food and the presence of specific IgE to several allergens. In addition to specific antibodies to latex fractions, we detected sensitization to pollens, without a distinct pattern between allergic or sensitized to latex patients, in 5 subjects, as follows: a) Timothy grass: Grass group $1, \mathrm{rPhl} \mathrm{p} 1, \mathrm{n}=$ 1; b) Berberine bridge enzyme, $\mathrm{rPhl} \mathrm{p} 4, \mathrm{n}=3$; c) Tree pollen: Olive pollen, nOle e 1 (common olive group 5), $\mathrm{n}=1$ and d) Plane tree, putative invertase inhibitor ( $\mathrm{rPla}$ a 2$), \mathrm{n}=1$. Two other patients were sensitized to: a) Lipid transfer protein (nsLTP): peanut (rAra h 9), $\mathrm{n}$ = 1; walnut (nJug r 3), $\mathrm{n}=2$; b) peach ( $\mathrm{rPru}$ p 3$), \mathrm{n}=2$; wheat (rTri a 14 ), $\mathrm{n}=1$; c) mugwort ( $\mathrm{nArt} \mathrm{v} 3$ ), $\mathrm{n}=1$; d) olive pollen (nOle e $7), \mathrm{n}=1$ and e) Plane tree ( $\mathrm{rPla}$ a 3 ), $\mathrm{n}=1$. Sensitization to profilins, annual mercury (rMer a 1), $\mathrm{n}=1$, and to cross-reactive carbohydrate determinants (CCD, nMUFX3), $\mathrm{n}=1$, were also observed (table 2).

\section{Discussion}

According to extensive reports, the profile of specific $\operatorname{IgE}$ to latex fractions varies according to the subject evaluated. Healthcare

Table 1 - Concordance ( $\mathrm{I}$ / total, \%) between presence (positive), absence (negative) or both (positive + negative) of specific IgE to recombinant latex allergens obtained by Immuno Cap ${ }^{\circledR}$ and ImmunoCap-ISAC ${ }^{\circledR}$ in patients allergic or sensitized to latex.

\begin{tabular}{lcccccc}
\hline \multirow{2}{*}{ Allergen } & \multicolumn{3}{c}{ Allergic $(\mathbf{n}=\mathbf{1 1})$} & \multicolumn{3}{c}{ Sensitized $(\mathbf{n}=\mathbf{1 4})$} \\
\cline { 2 - 7 } & positive & negative & total & positive & negative & total \\
\hline \multirow{2}{*}{ rHev b 1 } & $8 / 10$ & $1 / 1$ & $9 / 11$ & $4 / 6$ & $8 / 8$ & $12 / 14$ \\
& $80.0 \%$ & $100 \%$ & $81.8 \%$ & $75.0 \%$ & $100 \%$ & $86.0 \%$ \\
\hline \multirow{2}{*}{$\mathrm{rHev}$ b 3 } & $4 / 6$ & $5 / 5$ & $9 / 11$ & $3 / 5$ & $8 / 9$ & $11 / 14$ \\
& $75.0 \%$ & $100 \%$ & $81.8 \%$ & $60.0 \%$ & $88.9 \%$ & $79.0 \%$ \\
\hline \multirow{2}{*}{$\mathrm{rHev}$ b 5 } & $6 / 7$ & $4 / 4$ & $10 / 11$ & $2 / 3$ & $10 / 11$ & $12 / 14$ \\
& $85.7 \%$ & $100 \%$ & $91.0 \%$ & $66.7 \%$ & $90.9 \%$ & $86.0 \%$ \\
\hline \multirow{2}{*}{$\mathrm{rHev}$ b 6.01 } & $5 / 8$ & $3 / 3$ & $8 / 11$ & $2 / 4$ & $10 / 10$ & $12 / 14$ \\
& $62.5 \%$ & $100 \%$ & $73.0 \%$ & $50.0 \%$ & $100 \%$ & $86.0 \%$ \\
\hline \multirow{2}{*}{$\mathrm{rHev}$ b 8 } & $0 / 1$ & $9 / 10$ & $9 / 11$ & $1 / 1$ & $13 / 13$ & $14 / 14$ \\
& $0.0 \%$ & $90.0 \%$ & $81.8 \%$ & $100 \%$ & $100 \%$ & $100 \%$ \\
\hline
\end{tabular}


Table 2 - Patients allergic or sensitized to latex according to skin prick test (prick to prick) with fruits and vegetables and presence of specific IgE identified by ImmunoCAP-ISAC (sIgE > 0.3 ISU-E).

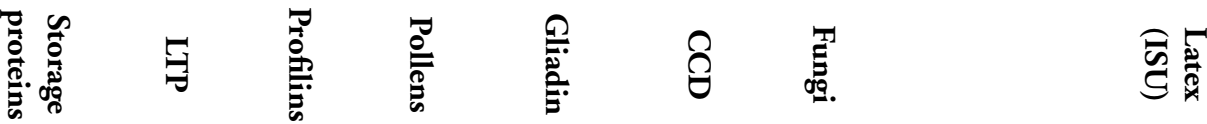

\begin{tabular}{|c|c|c|c|c|c|c|c|c|c|c|c|c|c|}
\hline \multicolumn{14}{|c|}{ Allergic } \\
\hline Pt\# & & & & & & & & & $\begin{array}{c}\mathrm{rHev} \\
\mathrm{b} 1\end{array}$ & $\begin{array}{c}\mathrm{rHev} \\
\text { b } 3\end{array}$ & $\begin{array}{l}\mathrm{rHev} \\
\text { b } 5\end{array}$ & $\begin{array}{c}\mathrm{rHev} \mathrm{b} \\
6.01\end{array}$ & $\begin{array}{c}\mathrm{rHev} \\
\mathrm{b} 8\end{array}$ \\
\hline 9 & $\begin{array}{c}\text { potato } \\
\text { avocado } \\
\text { pineapple }\end{array}$ & $\begin{array}{l}\text { nJug } r \\
2 \text { rAra } \\
\text { h } 6\end{array}$ & $\begin{array}{c}\text { nJu g r } 3 ; \\
\text { rAra h9; } \\
\text { rPru p 3; } \\
\text { nArt v 3; } \\
\text { nOle e } \\
7 \text {; rTri a } \\
\text { 14; } \\
\text { rPla a } 3\end{array}$ & - & $\begin{array}{l}\text { rPhl p 4; } \\
\text { nOle e1; } \\
\text { rPla a } 2\end{array}$ & - & - & - & 2.2 & 1.5 & 48.0 & 4.5 & 2.2 \\
\hline 12 & manioc & - & - & - & - & - & - & - & - & - & 7.4 & 1.4 & - \\
\hline 24 & $\begin{array}{l}\text { tomato / } \\
\text { potato } \\
\text { manioc }\end{array}$ & $\begin{array}{l}\text { nJug } \\
\text { r } 2\end{array}$ & - & - & $\begin{array}{c}\mathrm{rPhl} \mathrm{p} \\
\text { 4; nCyn } \\
\mathrm{d} \mathrm{1} \text {; } \\
\mathrm{nCyn} \mathrm{d} \\
3 ; \mathrm{rPla} \\
\text { a } 2\end{array}$ & - & nMUFX3 & - & 2.3 & 9.8 & $>100$ & - & 2.3 \\
\hline 28 & $\begin{array}{l}\text { mango / } \\
\text { jackfuit }\end{array}$ & - & - & - & rPhl p 7 & - & - & - & 12.0 & - & & - & 12.0 \\
\hline 37 & chestnut & - & - & - & & - & - & - & 5.6 & - & 19.0 & 9.3 & 5.6 \\
\hline 45 & papaya & - & - & - & & - & - & - & 0.6 & 0.8 & 1.3 & - & 0.6 \\
\hline 7 & negative & - & - & - & $\mathrm{rPhl} \mathrm{p} 1$ & - & - & - & 0.5 & - & - & 0.8 & - \\
\hline 55 & negative & - & nArt v 3 & - & $\mathrm{rPhl}$ p 4 & $\begin{array}{c}\text { rTri a } \\
19\end{array}$ & - & $\begin{array}{l}\mathrm{rCla} \\
\mathrm{h} 8\end{array}$ & - & 2.2 & 5.3 & - & - \\
\hline \multicolumn{14}{|c|}{ Sensitized } \\
\hline 42 & $\begin{array}{c}\text { papaya/ } \\
\text { pearl }\end{array}$ & - & - & - & - & - & - & - & 1.2 & 0.3 & - & 8.8 & - \\
\hline 13 & negative & - & $\begin{array}{l}\text { nJug r 3; } \\
\text { nArt v } 3\end{array}$ & - & - & $\begin{array}{c}\text { rTri a } \\
19\end{array}$ & - & - & - & 0.4 & - & - & - \\
\hline 41 & negative & $\begin{array}{c}\text { nJug } \\
\text { r } 2 \\
\end{array}$ & - & - & - & - & - & - & 3.0 & 22.0 & 7.2 & 1.5 & - \\
\hline 50 & negative & - & - & $\begin{array}{c}\text { rMer } \\
\text { a } 1\end{array}$ & - & - & - & - & - & - & - & - & 0.5 \\
\hline
\end{tabular}

LTP, Lipid transfer protein; peanut (rAra h 6, rAra h 9); walnut (nJug r 2, nJug r 3); peach (rPru p 3); wheat (rTri a 14, rTri a 19); mugwort (nArt v 3); Timothy grass ( $\mathrm{rPhl}$ p 1, rPhl p 4, rPhl p 7); olive pollen (nOle e 1, nOle e 7); plane tree (rPla a 2, rPla a 3); annual mercury (rMer a 1); cross-reactive carbohydrate determinants (CCD, nMUFX3). 
professionals are generally sensitized to $\mathrm{Hev}$ b $2, \mathrm{Hev}$ b 5, Hev b 6.02, and Hev b 13, while patients with spina bifida are sensitized to Hev b 1, Hev b 3, and Hev b $7(3,4)$. Recently, allergy to latex in patients undergoing multiple surgeries has been associated with specific IgE to rHeb v 5 and rHeb v 6.01 (4). Among our patients with myelomeningocele and latex allergy, $90.9 \%$ had specific IgE to Hev b 1 (5).

Although the levels of specific IgE to latex and fractions obtained by Immuno-CAP ${ }^{\circledR}$ were higher among latex allergic patients, they were not significantly different from those found in individuals sensitized to latex. Comparing these two methods (ImmunoCAP ${ }^{\circledR}$ vs. I-ISAC ${ }^{\circledR}$ ) we observed a high level of concordance considering both positive and negative results. Since these methods are different, the quantitative comparison of their results is not possible (table 1).

The I-ISAC ${ }^{\circledR}$ available commercially contains 5 recombinant latex allergens ( $\mathrm{rHev}$ b $1,3,5,6.01$, and 8 ), and using ImmunoCAP ${ }^{\circledR}$ we can quantify 8 fractions (rHev b 1, 3, 5, 6:01, 6:02, 8, 9, and 11). So, using ImmunoCAP ${ }^{\circledR}$ alone we would classify 11 patients as allergic and 14 patients as sensitized, whereas using I-ISAC ${ }^{\circledR}$ the results were 11 allergic and 9 sensitized. Five patients were not identified as latex-sensitized because I-ISAC ${ }^{\circledR}$ test does not contain the latex fractions to which they were sensitized ( $\mathrm{rHev}$ b 6.02, 9, and 11).

Despite the presence of antibodies against pollens, LTP and profilins in some patients, none of them reported symptoms related with intake of fruits and/or vegetables. However, they were submitted to SPT (prick to prick) for foods and some of them were positive for: papaya $(n=2)$, potato $(n=2)$, avocado $(n=1)$, chestnut $(n=1)$, jackfruit $(n=1)$, mango $(n=1)$, manioc $(n=1)$, tomato $(n=1)$, pear $(\mathrm{n}=1)$, and pineapple $(\mathrm{n}=1)$, and were negative for apple, banana, celery, fig, kiwi, melon and peach (table 2). Another point to be emphasized was the presence of specific IgE to pollens, grasses and trees to which our patients probably were not exposed.

Comparing results of SPT with specific IgE to all different components tested in I-ISAC ${ }^{\circledR}$, we did not observe a suggestive pattern to differentiate allergic and sensitized patients to latex, although we have found some patients with negative SPT and positive specific IgE to storage proteins, profilins and LTPs (table 2).

Some conditions may explain these findings. The food profile on I-ISAC ${ }^{\circledR}$ (walnuts, peanuts, peach, wheat) does not seem to be the most appropriate to investigate the latex-fruit syndrome, because it does not contain many foods known to cause of the syndrome (e.g. avocado, apple, celery, chestnut, fig, jackfruit, kiwi, manioc, mango, melon, papaya, peach, pear, pineapple, potato and tomato) $(3,4,5)$. In addition, latex-fruit syndrome is reported to be more frequent among healthcare professionals than in patients with myelomeningocele. These patients usually show asymptomatic sensitization, while healthcare workers may present clinical manifestations as well as anaphylaxis (10). In conclusion, we observed that both methods are effective in assisting the diagnosis of latex allergy (sensitization + symp- toms), but they differ in the assessment of sensitized patients (without symptoms) in the pediatric patients with myelomeningocele. The assessment of patients sensitized to latex is more complete when using the 8 recombinant latex fractions available in ImmunoCAP ${ }^{\circledR}$ compared with I-ISAC ${ }^{\circledR}$.

The negative predictive value of SPT for diagnosing food allergy in pediatric patients with myelomeningocele is high. In this population, the latex-fruit syndrome is better evaluated using fresh suspected food (prick to prick) than when using I-ISAC ${ }^{\circledR}$. In pediatric patients with myelomeningocele, the I-ISAC ${ }^{\circledR}$ test has proven not to be the best method for investigation of latex-pollen-fruit syndrome.

\section{Funding}

Fundação de Amparo à Pesquisa do Estado de São Paulo-FAPESP; process: 2009/5303-5.

\section{Conflict of interest}

The authors declare that they have no conflict of interest.

\section{References}

1. Kim TE, Park SW, Cho NY, Choi SY, Yong TS, Nahm BH, Lee $S$, Noh G. Quantitative measurement of serum allergen-specific IgE on protein chip. Exp Mol Med 2002; 34(2):152-8.

2. Nieto García A, Mazón Ramos A, Pamies Espinosa R, Caballero Gómez L, Oliver Jiménez F, Colomer Hernández N. Clinical importance of cross-reactivity between allergens. Allergol Immunopathol (Madr) 2004; 32(3):124-9.

3. Ebo DG, Hagendorens MM, De Knop KJ, Verweij MM, Bridts $\mathrm{CH}$, De Clerck LS, Stevens WJ. Component-resolved diagnosis from latex allergy by microarray. Clin Exp Allergy 2010; 40(2):348-58.

4. Garnier L, Selman L, Rouzaire P, Bouvier M, Roberts O, Bérard F, Bienvenu J, Bienvenu F. Molecular allergens in the diagnosis of latex allergy. Eur Ann Allergy Clin Immunol 2012; 44(2):73-9.

5. Bueno de Sá A, Araujo RFC, Cavalheiro S, Mallozi MC, Solé D. Profile of Latex Sensitization and Allergies in Children and Adolescents with Myelomeningocele in São Paulo, Brazil. J Investig Allergol Clin Immunol 2013; 23(1):43-9.

6. Ott H, Schröder C, Raulf-Heimsoth M, Mahler V, Ocklenburg C, Merk HF, Baron JM. Microarrays of recombinant Hevea brasiliensis proteins: a novel tool for the component-resolved diagnosis of natural rubber latex allergy. J Investig Allergol Clin Immunol 2010; 20(2):129-38.

7. Sampson HA, Aceves S, Bock SA, James J, Jones S, Lang D, et al. Food allergy: a practice parameter update-2014. J Allergy Clin Immunol 2014; 134(5):1016-25.e43.

8. Measurement of specific IgE antibodies with ImmunoCAP ISAC results in a broad spectrum allergen profile on a molecular level. Available at http://www.phadia.com/en-ZA/Products/Products/ ImmunoCAP-ISAC/ Accessed in November, 2014.

9. Canonica GW, Ansotegui IJ, Pawankar R, Schmid-Grendelmeier P, van Hage M, Baena-Cagnani CE, et al. A WAO - ARIA GA2LEN consensus document on molecular-based allergy diagnostics. World Allergy Organ J 2013;6(1):17.

10. Blanco Guerra C. Latex-fruit syndrome. Allergol Immunopathol (Madr) 2002; 30(3):156-63. 